\title{
The Morphemes -lar/-ler and -lik/-lık/-luk/-lük of Turkish Language Into Albanian and
} Romanian Languages

\author{
Dr. Spartak Kadiu \\ University of Tirana \\ spartakkadiu@yahoo.com
}

DOI:10.5901/mjss.2014.v5n19p641

\begin{abstract}
Turkish language has greatly influenced the Balkan's languages. Regardless of the fact that these languages are different from each-other, again in almost of them Turkish language has influenced with elements of its structure and lexicon. Turkish with elements of its structure has influenced as well on Albanian language and Romanian to. In this paper we will take a general view on grammatical elements of plural of Turkish language such as the morphemes -lar/-ler and the use of these morphemes in the word-formation of Albanian and Rumanian languages. Besides knowing suffixes like -xhi/-çi/-llëk/-çe/-li/-lli ecc. used with Turkish borrowed themes, we will focus on the using of these suffixes in Albanian and Romanian languages. Furthermore we will explain some derivated words in Albanian and Romanian languages and the using of these morphemes today.
\end{abstract}

Keywords: Morphemes -lar/-ler, -lık/-lik/-luk/-lük, Albanian Language, Romanian Language.

\section{Introduction}

For more than half a millenium, Turkish was the official language in much of the Balkan peninsula. It was the language of administration and of the market place; it was spoken in village as well as in towns; and, among populations that converted to Islam while retaining their native languages, Turkish had a sociocultural prestige added to the legal and practical importance it possessed for all of Turkey in Europe. It can be even be argued that it was the Turkish conquest which created the Balkans insofar as it still exists as a geopolitical and sociocultural entity of today. Under these circumstances, it is not surprising that the influence of Turkish on the Balkan lexicon in terms of derivational morphology, lexical items, and semantics has been significant and has lasted the modern period. (Friedman 1994: 521)

This new culture and this new religion which was set in the Balkans during the period of the Ottoman Empire, brought with it new concepts, which created the basis for introduction of words from other languages. As it is known, there exists a common corpus in the Balkans, composed of around 846 words, most of which are part of the active use of the languages of the Balkans. These words are related to religious concepts, concepts related to house furniture, to various ways of cooking and dishes, as well as with the characteristics of the person. These words did not damage the languages of the Balkans, despite of the long Ottoman invasion. As it is known, according to professor Çabej, the words introduced from Turkish belong to three time periods: from X - XIV century, from XV - XVI century and from XVII - XIX century. The first period has fewer introductions. While the words introduced in the second period are more numerous. (Çabej 1975) The third period is noted for more words introduced as well as for the development of literature with Arabic letters. This was known in the Albanian literature as the literature of the 'bejtexhi-s' (comic instant poets). Albanian language has borrowed more than 4000 words, from which more than 1400 have been included in the Dictionary of the Albanian Language. Meanwhile, in the Dictionary of the Oriental Words of Tahir Dizdari, there are 4406 direct introductions from Turkish; he emphasizes there also the lexical meaning as well as the phonetic alterations of these words.

From a lexical point of view, the influence of Turkish is one of the most salient characteristics of the languages of the Balkan linguistic league. In fact, Miclosich's (1884) study of the influence of Turkish on the languages of Southeastern and Eastern Europe is one of the earliest works in the field Balkan linguistics. (Friedman 1994: 521)

According to Kazasis is, however, general agreement that the impact of Turkish on the domains of morphology and syntax was much less significant than its impact on the lexicon. (Sandfeld 1930, p. 159; Hazai 1961, p.102) 
Again according to Kazasis Turkish influence on the sound system of the standart Balkan languages has been minimal. The main vestiges left by Turkish on standard Balkan phonology are indirect ones, namely an increase in the frequency of occurrence of some sounds, such as the sound -dz in Albanian, Rumanian, and the South Slavic languages with which we are concerned. That happened because those languages adopted Turkish words and suffixes containing that sound. Rumanian, already had that sound in words inherited from Latin, such as ginere 'son-in-law', genunchi 'knee', a trage 'to pull', etc. (Kazazis 1972: 99)

Turkish influences do not simply have a lexical nature. In some Balkan languages they influenced a grammar. In all of the Balkan languages, a part of Turkish suffixes which were introduced along with Turkish words, became isolated from borrowed words and started to be productive with non Turkish roots. As it is well known, suffixes with a greater use in these languages are -lı,-li,-lu,-lü,-Cl,-ci,--cu,-cü,-lık,-lik,-luk,-lük,-ca,--ce,-ça,-çe. It should be pointed out that despite using and borrowing these words, Balkan Languages did not acquire all the meanings these suffixes have in Turkish language.

According to Miklosich, who was first to write on these suffixes in Balkan languages, -lı,-li,-lu,-lü can be found in Serbian, Bulgarian and Albanian languages,-Cl,-ci,-Cu,-cü, can be found in all of the Balkan languages except for Greek language, -lık,-lik,-luk,-lük can be found in all of the Balkan languages except for Greek language, -ca, -ce can be found in Serbian, Bulgarian and Albanian languages, -kar can be found in all of the Balkan languages. (Latifi 2006: 502)

As known from the lexicological studies, the Romanian language has borrowed around 3900 words out of which 1700 are of daily use. Researchers on Turkish borrowings in Romanian are numerous. To mention a few: Miklosich, Lazar Saineanu, Theophil Lobel, Karl Lokotsch, Heine F. Wendt, M. Guboğlu, Muammer Burlu and Kerim Altay. M. Guboğuz worked for their exact determination in his work "Romanya Türkolojisi ve Rumen dilinde Türk sözleri hakkında bazı araştırmalar". Later on, the linguist of Turkish origin, Kerim Altay, in the four dictionaries of Romanian that he prepared, notes that the group of words used daily may reach up to 2000 words. This conclusion gives also the essence of his work. "Rumencedeki Türkçe kelimeler".

In relation to suffixes borrowed in Rumanian language we can mention Werner Bahner (1958). In his work he emphasizes that -giu suffix continues to be productive in today Rumanian as a pejorative suffix. Hi gives examples such as laptagiu, cazangiu, cafegiu, odagiu, hangiu, borangiu etc. (Kazazis 1972:102-111). In their work "Suffixes in Albanian Language" Xhuvani, A. and Qabej, E. emphasize that -lik suffix is also part of the Rumanian language. The examples they give are ciflig, geamlic, babalic, caraghioslic. (Latifi: 2006, pp. 502)

In this paper we will focused on -lar,-ler and -lık,-lik,-luk,-lük morphemes. If we refered to the Turkish grammar for these morphemes they have these meanings. -lar/-ler morpheme forms the plural in Turkish. It is also a word formation morpheme. It identifies collective nouns. It is added to nouns of a particular quality. This suffix forms nouns that denote profession sets different from the nouns denoting professions. We will give some examples from Turkish that are traduced into Albanian language.

$\begin{array}{llll}\text { Turkish } & \text { Albanian } & \text { Turkish } & \text { Albanian } \\ \text { bakal } & \text { shitës ushqimor } & \text { bakallar } & \text { shitësit ushqimorë } \\ \text { kasap } & \text { kasap } & \text { kasaplar } & \text { grupimi i kasapëve } \\ \text { mimar } & \text { arkitekt } & \text { mimarlar } & \text { grupi i arkitektëve }\end{array}$

a) This morpheme forms also collective nouns like examples below.

$\begin{array}{llll}\text { Turkish } & \text { Albanian } & \text { Turkish } & \text { Albanian } \\ \text { insan } & \text { njeri } & \text { insanlar } & \text { njerëzia } \\ \text { çocuk } & \text { fëmijë } & \text { çocuklar } & \text { fëmijëria } \\ \text { dağ } & \text { mal } & \text { dağlar } & \text { male }\end{array}$

b) Also they form last names denoting collective nouns. E.g. Ahmet-ler, Doğan-lar, Düzceli-ler.

Nouns denoting professions, titles, nations, rulers, inhabitants of a country or town from general representative nouns. E.g.Türkler (turqit), İtalyanlar (italianët), Habsburglar (Habsburgët), Oğuzlar, Atatürkçüler, Aleviler (alevitë). When used after proper nouns, this suffix denotes similarities. E.g. Mithat Paşalar, Namık Kemaller, Londralarda (ata që janë në Londër). 
c) The suffixes -gil and -ler in the Anatolia speech form collective proper nouns that can extend by the -ler suffix such as Tuzcu-giller. The suffixes -gil and -giller form family last names and terms.

When added to the noun oğul and proper nouns as an indefinite syntagma, beg names are formed. Example Aydınoğulları,Candaroğulları,Karamanoğulları,Ramazanoğulları,Saruhanoğulları etc.

d) This morpheme forms toponyms, mountain ranges.E.g. Çifte-ler, Çoban-lar, Tatar-lar, Orhan-lar, Toros-lar (malet Toros), Alp-ler (Alpet), Atlas-lar (Atlaset) Ada-lar (Ishujt), Antil-ler (Antilet). These suffixes have formed nouns to replace Arabic terms and western loanwords:

$\begin{array}{llll} & \text { Arabic } & \text { Turkish } & \text { Albanian } \\ \text {-ler } & \text { futut } & \text { mantarlar } & \text { kërpudhat } \\ \text {-liler } & \text { zülhasale } & \text { kavuzlular } & \text { glumimoret } \\ \text {-giller } & \text { necliye } & \text { buğdaygiller } & \text { graminoret }\end{array}$

This suffix was used for the Arabic and Persian words that were introduced in the ottoman Turkish and during the expansion of the Turkish Empire e.g. memurin = memurlar, ulema = bilginler etc. This suffix was very vivid during this period as it was added to loanwords or terms or to find the equivalent to the western borrowed terms. (Turkish Grammars, Korkmaz, 2007, Banguoğlu 2000).

The foreign languages impact in the Albanian grammatical structure, as justly put by different scholars who studied the Albanian language was either zero or it affected some particular elements. In this perspective, as far as the Turkish impact is concerned, in the suffix system used to form the plural, the suffixes -ler and -lar, have the Albanian variants -lerë and -llarë, thus adding the ending -ë. (Boretsky 1975; Hysa, 1998: 149-153)

In Albanian along with some borrowed words from Turkish have entered the plural suffixes of Turkish -llar,-ler which in analogy with the plural of the type fshatarë (villagers) have also take the morpheme -ë at the end: agallarë, atllarë, baballarë, subashllarë, ustallarë, xhaxhallarë, bejlerë, dervishlerë, efendilerë, kadilerë ect. A part of these words have passed into old unused words. (Gramatika e gjuhes shqipe 1, Akademia e Shkencave e Shqiperisë 2002: 100)

This morpheme of Turkish also appear in the Albanian Patronymic profession derived names. Most of these profession names were replaced with Turkish names, which, as Sh. Demiraj describes, "in Albanian many more nouns were introduced than adjectives and verbs from Turkish". Since the Turks ruled Albania by Albanian officials, the so-called derebej, Albanian pashas were appointed as governors of the pashaliks. Thus, the patronym Pasha - Pashaj and its derived variants Pashali, Pashalli, Pashallari, are often found in Albanian names. (Bidollari 2010: 111) The new religion that Ottoman Turks brought was accompanied with relevant institutions and people that ran them, with religious hierarchy titles and functions, with Patronyms there of Hafizi - Hoxha - Hoxhja - Hoxhati - Hoxhalli - Hoxhallari, which is the most prevalent Patronym in the Albanian territory. Patronyms derive from the Bektashi as well such as Dervishllari, Dervishleri with reference to the suffix -lar. According to Bidollari, the names of other families, those ending in -llar, such as Meçollari, particularly frequent in the Permeti region, are singularized plurals, i.e. from one Meço the plural was formed, his entire family or kinship were called Meçollarë, then it singularized to Meçollari.

According to Turkish Grammars the suffix -lık/-lik/-luk/-lük is the most productive suffix in Turkish. In Albanian it is borrowed from Turkish with the word. This suffix has two functions. It forms the destinativ. (Banguoğlu 2000: 193-194; Korkmaz 2007: 57)

\section{Turkish Albanian \\ elli kuruş-luk bilet (biletë 50 qindarkëshe) \\ üç gün-lük iş (punë për tre ditë)}

It forms adjectives in sense of belonging and is placed behind the name. It has the meaning of preposition 'for'.

$\begin{array}{llll}\text { Turkish } & \text { Albanian } & \text { Turkish } & \text { Albanian } \\ \text { bayramlık } & \text { festë } & \text { bayramlık elbise } & \text { veshje feste (veshje për festë) }\end{array}$


kiralık

me qira

kiralık ev

shtëpi me qira

Like a morpheme that create new words it has a lot of meanings. Through it can be formed the nominalized adjectives that show items, tools, instruments.

$\begin{array}{llll}\text { Turkish } & \text { Albanian } & \text { Turkish } & \text { Albanian } \\ \text { göz } & \text { sy } & \text { gözlük } & \text { syze } \\ \text { kulak } & \text { vesh } & \text { kulaklık } & \text { kufje }\end{array}$

It is a very useful and forms generally names and surnames. The main function is to give the sense of something that is used for a particular purpose or action. Semantic structure of the word after which it is added and its function makes this suffix to win a variety of functions other than its main function. This suffix forms names that give the meaning to a particular function.

$\begin{array}{llll}\text { Turkish } & \text { Albanian } & \text { Turkish } & \text { Albanian } \\ \text { akşam } & \text { mbrëmje } & \text { akşamlık } & \text { veshje mbrëmje } \\ \text { baş } & \text { kokë } & \text { başlık } & \text { titull }\end{array}$

It forms the place in which are a lot of same things.

$\begin{array}{llll}\text { Turkish } & \text { Albanian } & \text { Turkish } & \text { Albanian } \\ \text { çift } & \text { çift } & \text { çiftlik } & \text { çiftlig } \\ \text { fidan } & \text { fidan } & \text { fidanlık } & \text { fidan } \\ \text { ağaç } & \text { pemë } & \text { ağaçlık } & \text { pemishte } \\ \text { zeytin } & \text { ulli } & \text { zeytinlik } & \text { ullishtë }\end{array}$

This suffix forms names of places.

$\begin{array}{llll}\text { Turkish } & \text { Albanian } & \text { Turkish } & \text { Albanian } \\ \text { arnavut } & \text { shqiptar } & \text { Arnavutluk } & \text { Shqipëri } \\ \text { ayva } & \text { ftua } & \text { Ayvalık } & \\ \text { zeytin } & \text { ulli } & \text { Zeytinlik } & \end{array}$

With this suffix is constructed the repetitive words that are characteristic of the Turkish language. (Ikimeler - dublets)

$\begin{array}{lllll}\text { Turkish } & & \text { Albanian } & \text { Turkish } & \text { Albanian } \\ \text { Gül } & \text { trëndafil } & \text { gülüstanlıkvend luleshgüllük gülüstanlık } & \text { vend i begatë } \\ \text { gün } & \text { ditë } & \text { güneş diell günlük güneşlik } & \text { ditë me diell }\end{array}$

It forms of names with the feature set of tools.

$\begin{array}{llll}\text { Turkish } & \text { Albanian } & \text { Turkish } & \text { Albanian } \\ \text { biber } & \text { spec } & \text { biberlik } & \text { mbajtëse piperi } \\ \text { çakmak } & \text { çakmak } & \text { çakmalık } & \text { vend çakmakësh, } \\ \text { tuz } & \text { kripë } & \text { tuzluk } & \text { kripore }\end{array}$

It forms the profession's name and specific fields of study.

$\begin{array}{llll}\text { Turkish } & \text { Albanian } & \text { Turkish } & \text { Albanian } \\ \text { asker } & \text { ushtar } & \text { askerlik } & \text { ushtri } \\ \text { avukat } & \text { avukat } & \text { avukatlık } & \text { avokati } \\ \text { bakkal } & \text { bakalli } & \text { bakkallık } & \text { shitës }\end{array}$

This suffix added to adjectival themes formed with the suffix -ci or not, and forms the community of people who follow the same direction, religious beliefs, philosophical, political convinction. 


$\begin{array}{llll}\text { Turkish } & \text { Albanian } & \text { Turkish } & \text { Albanian } \\ \text { toplumcu } & \text { social } & \text { toplumculuk } & \text { socializëm } \\ \text { atatürkçü } & \text { ataturkist } & \text { atatürkçülük } & \text { ataturkizëm } \\ \text { bektaşi } & \text { bektashi } & \text { bektaşilik } & \text { bektashizëm }\end{array}$

This suffix foms names and titles that indicate positions.

$\begin{array}{llll}\text { Turkish } & \text { Albanian } & \text { Turkish } & \text { Albanian } \\ \text { ağa } & \text { aga } & \text { ağalık } & \text { të qenit aga } \\ \text { imam } & \text { imam } & \text { imamlık } & \text { profesioni i imamit }\end{array}$

kaymakamnënprefekt

kaymaklık

profesioni i tij

It forms also unconcrete names with general quality from names and adjectives.

$\begin{array}{llll}\text { Turkish } & \text { Albanian } & \text { Turkish } & \text { Albanian } \\ \text { ana } & \text { nënë } & \text { analık } & \text { amësia } \\ \text { çocuk } & \text { fëmijë } & \text { çocukluk } & \text { fëmijëri } \\ \text { haydut } & \text { hajdut } & \text { haydutluk } & \text { hajdutëri }\end{array}$

It also forms the names that show color, giving the spread understanding and mastery of that color.

$\begin{array}{llll}\text { Turkish } & \text { Albanian } & \text { Turkish } & \text { Albanian } \\ \text { ak } & \text { e bardhë } & \text { aklık } & \text { bardhësi } \\ \text { kara } & \text { e zezë } & \text { karanlık } & \text { errësirë } \\ \text { yeşil } & \text { e gjelbërt } & \text { yeşillik } & \text { gjelbërim } \\ \text { Turkish } & \text { Albanian } & \text { Turkish } & \text { Albanian } \\ \text { bol } & \text { mjaftueshëm } & \text { bolluk } & \text { bollëk } \\ \text { deli } & \text { budalla } & \text { delilik } & \text { budallallëk } \\ \text { yavaş } & \text { ngadalë } & \text { yavaşlık } & \text { ngadalësi }\end{array}$

This suffix is added to participle formed by the suffix -ar, -maz and forms unconcrete names.

$\begin{array}{llll}\text { Turkish } & \text { Albanian } & \text { Turkish } & \text { Albanian } \\ \text { anlaşılır } & \text { i kuptueshëm } & \text { anlaşılırlık } & \text { mirëkuptim } \\ \text { anlaşmaz } & \text { i pakutueshëm } & \text { anlaşmazlık } & \text { keqkuptim }\end{array}$

This suffix forms names that have the meaning 'of being in a group, or collection' adding to the numerals and adjectives.

$\begin{array}{llll}\text { Turkish } & \text { Albanian } & \text { Turkish } & \text { Albanian } \\ \text { bir } & \text { një } & \text { birlik } & \text { njëshe } \\ \text { bin } & \text { njëmijë } & \text { binlik } & \text { një mijëshe }\end{array}$

This suffix adding to names settling time forms names and adjectives that are included in that unit of time.

$\begin{array}{llll}\text { Turkish } & \text { Albanian } & \text { Turkish } & \text { Albanian } \\ \text { asırlık } & \text { shekull } & \text { asırlık } & \text { shekullor } \\ \text { hafta } & \text { javë } & \text { haftalık } & \text { javor }\end{array}$

This suffix is used to replace the Arabian compound suffix -iyyat>-iyet, as in the words hakimiyet, insaniyet, Milliyet, or other words that have entered from Arabian.

\begin{tabular}{|c|c|c|c|}
\hline $\begin{array}{l}\text { Turkish } \\
\text { dünvevi }\end{array}$ & Albanian & Turkish & $\begin{array}{l}\text { Albanian } \\
\text { botë (dvniallëk) }\end{array}$ \\
\hline
\end{tabular}


husumet

düşmanlık

armiqësi (Banguoğlu 2000:195-196)

In Albanian this suffix is used. The formation of abstract nouns in Albanian language is made even with some foreign suffixes such as -llëk, -izëm, -azh, -urë. Turkish suffix -lık/-lik/-luk/-lük (-llëk) has been used to form from Turkish words, and in some cases from other words, nouns that denote quality or abstract characteristics, usually with a pejorative stylistic coloration: avokatllëk (avokat), batakçëllëk (batakçi), budallallëk (badalla), fodullëk (fodull), fukarallëk (fukara), hajdutllëk (hajdut), maskarallëk (maskara). These words mostly belong to spoken language and their numbers have been reduced constantly. In literary language, many of these words were substituted by words formed with suffixes of Albanian origin and Albanian words. So budallallëk is substituted by marrëzi, hajdutllëk by kusari or vjedhje etc. (Gramatika e gjuhes shqipe 1, Akademia e Shkencave e Shqipërisë 2002: 143)

This Turkish suffix was first introduced in Albanian language within Turkish words and then latter it was used in Albanian words, forming concrete, abstract and ethnic nouns as well as names of places.

According to Xhuvani and Çabej, Turkish words are used with a concrete meaning, for example arallëk, batakllëk, çiftlik, hashllëk, kallaballëk, maxhallëk, xhamllëk, with an abstract meaning, for example akçillëk, avukatllëk, batakçillëk, budallallëk, bejllëk, dembellëk, dynjallëk, fodullëk, fukarallëk, hajdutllëk, haxhillëk, karshillëk, maskarallëk, ogursuzlluk, qeratallëk, sakatllëk, baballëk is also part of this category. Pashallëk word has an abstract and geographic meaning. Another such word is nikoqirllëk, from nikoqir with a Greek origin. Some Albanian nouns with an abstract meaning are for example evgjitllëk, njerëzillëk, pabesllëk, fshatarllëk, pleqërillëk, sëmundllëk, zotnillëk. This suffix is present in Albanian language in different forms, i.e. -lik, -llik, -llëk, -lluk, according to dialects and according to the level of preservation of these original Turkish forms from these dialects. They add also that this suffix is used by Bogdani in the word perëndillëk, denoting Impero. (Bogdani I 36, 11 - Boçari 5. - Kullurioti, Abetari 57. - Meyer 33, 109, Alb. Studien I 20. - Pekmezi 221. - Weigand, Alb. Gram. 39. - Cipo 41. - Leskien 318. - Pascu 407 vv. - Lambertz, Lingua Posnaniesnis VII 102. - Mladenov Etimologiçeski i pravopisen reçnik nga bg. knizovenj eziknj 9.12. - Andriotis 134.) (Xhuvani, Çabej 1962: 67-68)

Turkish suffixes,-Cl,-ci,-cu,-cü (-çi) and (-xhi) were very productive in Albanian language for the formation of active nouns but in the course of time they were substituted by Albanian suffixes. A series of words formed by these suffices are used to this day such as bojaxhi (paint), fshesaxhi (broom), hallvaxhi (halva), hanxhi (inn), kallajxhi (tin), qiraxhi (rent), shakaxhi (joke), sahatçi (clock), teneqexhi (tin), zanatçi (craft). The major part of them belongs to the historic lexicon. In a series of cases this suffix has either taken or is taking a pejorative coloration: kalemxhi. (Gramatika e gjuhes shqipe 1, Akademia e Shkencave e Shqipërisë 2002: 135)

Amongst the words of the common Balkan group which are found in the Albanian and the Romanian language are also adet, at, bajrak, baklava, beqar, bereket, bostan, çadër, çarçaf, çorap, dollap, fixhan, haraç, hyzmeqar, kallaj, kajsi, konak, kurban, kusur, limon, liman, merxhan, odë, legen, pehlivan, qilim, peshqesh, qira, sahan, sokak, tas, tavan, tepsi, vezir, xhami, zor, zymbyl etc.

Some other examples from Romanian language are ascherliu and ascher < asker, arzai < arzu, bacan, bacal < bakkal, elec < yelek, boia < boya, otuzbir < otuzbir bir kart oyunu, ghela < tavla oyundaki gele, baş < baş (Buescu, 1962).

Possibly overt Turkisms are the very numerous Balkan idiomatic expressions, greeting formulae, sayings, and proverbs borrowed from Turkish and containing one or more lexical Turkisms - some of the latter are never (or very rarely) used outside of such expressions: cf. Thomaj, 1965, pp. 172-173; Dimitrescu 1958, p.p. 171-172. However, a considerable number of Turkish idiomatic expressions, formulae, etc. have been wholly translated into native terms, so that few people today would suspect their Turkish origin. Linguists have tented to underestimate the role of Turkish in the creation of the common phraseological stock shared by the Balkan languages. (Kazazis 1972: 96-97)

In Romanian are used the suffixes -lık/-lik/-luk/-lük, ,-Cl,-ci,-cu,-cü. The most usuful suffix is -lâc, -lic (Romanian) $<$ (Turkish) -lik / lik. This is a very productive suffix. Generally it forms abstract nouns like hagialâc (hacılık), sürgünlük (surghiunlâc), it forms adjectives like caraghiozlâc (komik), hainlâc (hainlik), mucalitlâc (komik anlatim sekli), siretlic (kurnazlık), it forms names of professions like hamalâc (hamallık), it forms name of places like pasalâc (paşalık), it forms examples like boccealâc (bohçalık), calabalâc (kalabalık), mezelic (mezelik), avocatlâc, berbantlâc, crailâc, senatorlâc ect. This suffix in Romenian is replaced with the suffixs -ie. Examples hainie - hainlâc (hainlik), murdarie - murdarlâc (kirlilik), surghiunie - surghiunlâc (sürgünlük) etc. 
Other suffixes are the suffix -giu, -ciu (Romanian) < (Turkish) -ci, çi: Example abagiu (abacı), boiangiu (boyacı), cafegiu (kahveci), cherestegiu (keresteci), ciubucciu (çubukçu), conacciu (konakçı), dughengiu (dügenci), giuvaergiu (mücevherci), harabagiu (arabacı), herghelegiu (hergeleci), iaurgiu (yogurtçu), papugiu (pabuççu-ayakkabıcı), pastramagiu (pastırmacı), simigiu (simitçi), tinichigiu (tenekeci), tutungiu (tütüncü), zarzavagiu (zarzavacı). It forms words that express the negative features of personalities like haramgiu (haramcl), mascaragiu (maskaracı). It is not very produtive nowdays. Other suffix is -iu < (Turkish) -i / -i. It forms examples like conabiu (vişne renginde), fistichiu (fistık renginde) (Saineanu 1900).

Nouns referring to concrete objects were not spared either. We get an idea of what must have happened to some of them, when we read the following passage on Rumanian: "words borrowed from neighbouring languages were often eliminated deliberately, under the impact of the fashion which wanted everything to come from West. Such words as han 'inn' (Turkish han), birt 'alehouse', suliman 'make-up', macat 'blanket', etc. were replaced by hotel, restaurant, fard, cuvertura. At a certain moment it became difficult to sell a merchandise under its old name, which had begun to characterize rustic varieties, or junk, whereas under their French name the same commodities could be sold at higher prices" - Graur 1967, p.56. (Kazazis 1972:112)

Kazasis says that the stylistically marked Turkisms have enriched the expressive and stylistic potential of every Balkan Language (Krajni 1965, pp. 149, 151; Stojkov 1952, pp. 169-170; Triantaphyllides (1963a, pp. 112-114.) Some of them have pejorative overtones, others are labelled as ironical or derisive, some carry the epic overtones typical of certain historical words, stil others are characterized as vulgar. All of those connotative shades are used for stylistic effect by Balkan speakers and writers (Mircev 1952, p. 124; Skaljic 1966, p. 16; Saineanu 1900, pp. 256-257.)

According to Kazazis some lexical Turkisms, of all stylistic categories, constitute more or less large derivational families, which may have been additional factor in their survival and vitality (Skok 1935, p. 252; Bronsert 1968, p. 110).

Other loanwords which have a very good change of surviving for a long time are those stylistically neutral ones which have entered the basic vocabulary of a given language, that is those which refer to concepts or concrete objects of everyday life. For example, Albanian çerek in the sense of 'quarter of an hour' (Turkish çeyrek), or the various words for pocket (Turkish ceb); Albanian xhep, Bulgarian dzob and dzeb, Macedonia dzeb, Serbokroatian dzep. (Kazasis 1972: 113)

From the Language Dictionary of 1954 are selected these examples with suffix -lık,-lik,-luk,-lük borrowed from turkish lanuage.

AXHAMILLËK-U em. shm. Axhamillëqe punë prej axhamiu. BAKALLËK-u em. puna e bakallit. BATAKÇILLËK-U em, shm. Batakçillëqe puna që bën batakçiu; mashtrim. BOLLËK-U em. mbushullim, buri, hape. BOSHLLËK-U em, shm. Boshllëqe zbrazëtirë, golle. BUDALLALLËK-U em, shm. Budallallëqe marrëzi. ÇILIMILLËK-U em. shm. çilimillëqe punë çilimish, marrëzira. DALLKAUKLLËK-U em, shm. Dallkaukllëqe sjellje, punë dallkaukësh. DAMAZLLËK-U em. të mbajturit e një kafshe për mbarë. DYNJALLËK-U em.: kish rënë nga -u, s'qe më i pasur siç kish qenë: s'ka -, s'është i rrahur me jetë. FODULLËK-U em. të qenët fodull. FUKARALLËK-U em. vobeksi, varfëri. HAMALLËK-U em. 1 haka e hamallit: paguaj-un: 2. puna që bën hamalli: fig. punë e rëndë, që s'kërkon zotësi të madhe, punë pa përfitim. HAXHILLËK-U em. udhëtimi që bëhet për në vendet e shenjta fetare. HORRLLËK-U em. shm. Horllëqe, 1. punë horash, poshtërsi. 2. qesat, krizë: varfëri. HOVARDALLËK-U em, shm. hovardallëqe të qenët hovarda, cilësia e atij që është hovarda. KAPADAILLËKU em, shm. kapadaillëqe veti, punë, qëndrim kapadaish. KAPSLLËK-U em. të qenët kaps, shtërzim barku. KOKURLLËKU em. muri i grykës së posit. MUSHTULLUK-U em. shm. -ë sihariq. PARMAKLLËK-U em, shm. -e një radhë parmakësh. PEHLIVANLLËK-U em, shm. pehlivanllëqe akrobaci (në kuptimin figurative). QERRATALLËK-U em. shm. qerratallëqe djallëzi, prapamendi. QESATLLËK-U em. mungesë pune në tregti, krizë ekonomike. SAKATLLËK-U em. të qenët sakat: një e metë trupore: ka një -. SARALLAK-U em. mjek. të verdhët (sëmundje) SPAHILLËK-U em. (vjet.) shërbimi i spahive, të dhjetat që merrte spahiu si një të drejtë të tij. SYNETLLËK-U em. ceremony që zhvillohet, kur bëhet djali synet. SHEJTANLLËK-U em, shm. shejtanllëqe djallëzi, dreqni. TERSLLËK-U em, shm. tersllëqe, prapësi: na sjell -.

From the Language Dictionary of 1980 are selected these examples with suffix -lık,-lik,-luk,-lük borrowed from turkish lanuage. 
AGA, -I m. sh. -LLARË, -LLARËT. 1. Pronar tokash më i vogël se beu. AGALLAR, -I m. sh. -Ë. -ËT bot. Bimë barishtore shumëvjeçare. Me kërcell të gjatë, me fletë gjatoshe e me push, që rritet në livadhe e në gurishta dhe që lulëzon në qershorgusht. AGALLARI, -A f. përmb. vjet. Tërësia e agallarëve. Agallarët. AGALLESH/Ë, -A f. sh. -A, -AT vjet. shih AGESH/Ë, -A. AGALLËK, -U m. 1. vjet. Të qenët aga; të jetuarit si aga. Rronte me agallëk. Bënte agallëk. 2. keq. Sjellje prej agai, qëndrim prej agai; të jetuarit në kurriz të të tjerëve si aga. E la agallëkun. AGESH/Ë, -A f. sh. -A, -AT. 1. vjet. E shoqja e agait. AKRABALLË/K, -KU m. sh. -QE, -QET keq. Përkrahje që u jepet miqve e farefisit në dëm të interesave të përgjithshme; miqësi e sëmurë. ARALLË/K, -KU m.sh. -QË, -QET vjet. vend i zbrazët, hapësirë e lirë midis dy sendeve, largësi; plasë. ARGËLLËK, -U m. etnogr. vjet. Të hollat që i jepte dhëndri familjes së nuses para martesës për të përgatitur pajën e saj. AVASHLLËK, -U m. bised. Ngadalësi e madhe, plogështi. AVOKATLLË/K, -U m.sh. -QE, -QET bised., keq. Mbrojtja dhe përkrahja me fjalë e dikujt tjetër, pavarësisht nëse ky ka apo nuk ka të drejtë. AXHAMILLËK, -U m.sh. -QE, QET thjeshtligj. Papjekuri prej fëmije, punë prej axhamiu, kalamallëk. BABA, -I m.sh. -LLARË, -LLARËT. BABALLËK, -U m.sh. -Ë, -ËT ndërt. Dru i shkurtër e i trashë, që vihet nga kulmi i çatisë pingul mbi trarët e tavanit dhe mban kulmarin. BABALLËK, -E mb. bised. i patëkeq, i shtruar, shpirtmirë; i padjallëzuar, babaxhan. BAKALLË/K, -KU, m. sh. -QE, -QET vjet. Sendet që shiste bakalli në dyqanin e tij. BASHLLËK, -U m.sh. -Ë, -ËT vjet. Gur i madh, zakonisht i gdhendur, që vihej si mbështetje në anët e një qemeri ose të një oxhaku.BATAKÇILLË/K, -KU m.sh. -QE, -QET. Sjellje e veprim prej batakçiu.BEJLLËK, -U m.hist. Të qenët bej; vendi që zinte beu dhe titulli i tij. BEQARLLËK, -U m. bised. Shih BEQARI, A. BUDALLALLË/K, -KU m.sh. -QE, -QET bised. Të qenët budalla; marrëzi.BURULLUK, -U m. sh. -Ë, -ËT. Pëlhurë, zakonisht e bardhë, e hollë dhe e rrallë, që përdoret për perde, për shami koke etj.; napë.ÇILIMILLË/K, -KU m.sh. -QE, QET bised. vet. nj. Vetia e një njeriu të papjekur.DALLKAUKLLË/K, -KU m.sh. -QE, -QET bised., keq. Qëndrim, veprim a sjellje prej dallkauku. DEMBELLËK, -U m. bised. Dembeli, dembelizëm, përtaci. DUMBARALLË/K, -KU m. sh. -QE, -QET bised. Hile, rreng. DYNJALLËK, -U m. bised. Shih BOT/Ë, -A. FODULLËK, -U m. bised. Të qenët fodull, sjellje a qëndrim prej fodulli. FUKARALLËK, -U m. bised. Varfëri. GOMARLLË/K, -KU m.sh. -QE, -QET thjeshtligj. Gomari, marrëzi. HAMALLË/K, -KU m. sh. -QE, -QET. Mbartja, ngarkimi a shkarkimi i mallrave zakonisht me krahë, puna që bën hamalli.HORRLLË/K, -KU m.sh. -QE, -QET bised. Puna a veprimet e një njeriu të lig e me vese; veprim i poshtër që bëhet nga një njeri i pacipë e i pander, sjellje prej horri. JESHILLË/K, -KU m.sh. -QE. -QET bised. gjelbërim, blerim. KALAMALLË/K, -KU m.sh. -QE, -QET bised. Të qenët kalama nga mendja, qëndrim e sjellje prej kalamani. KARAGJOZLLË/K, -KU m.sh. -QE, -QET. Veprim e sjellje prej karagjozi. MASKARALLË/K, -KU m.sh. -QE, -QET bised. Të qenët maskara; veprim e sjellje MATRAPAZLLË/K, -KU m. sh. -QE, -QET bised., keq. Puna e matrapazit.MATUFLLËK, -U m. bised. Të qenët matuf, gjendja e atij që është bërë matuf.MAXHALLËK, -U m.sh. -E, -ET Pajandër. MOÇALLËK/E, -JA f.sh. -E, -ET. Dru që është futur në furrë për ta bërë qymyr, po nuk është djegur mirë.

MUSLLU/K, -KU m.sh. -KË, -KËT dhe -QE, -QET. Lëfyt i metaltë, që hapet e mbyllet, i cili vihet në anë ose në fund të një ene për të nxjerrë prej saj ujin a ndonjë lëng tjetër. MUSHTULLUK, -U m.sh. -Ë, -ËT vjet. Lajm i gëzuar që i jepet dikujt, sihariq. PAZARLLË/K, -KU m.sh. -QE, -QET. Bisedë që bëjnë blerësi dhe shitësi.PEHLIVANLLË/K, -KU m.sh. -QE, -QET keq. Dredhi a mashtrim që përdor dikush për t'i shpëtuar pa dëm një gjendjeje të vështirë a një rreziku, për t'u hedhur hi syve të tjerëve etj. PISLLËK, -KU m. sh. -QE, -QET bised. ndyrësi, papastërti, luftoj (zhduk) pisllëkun.

QERRATALLË/K, -KU m.sh. -QE, -QET bised. Veprim i shkathët, por dredharak.SELAMLLËK, -KU m.gj. -QË, -QET vjet. Godinë e veçantë, pjesë shtëpie ose dhomë pritjeje vetëm për burrat në shtëpitë e pasura myslimane.SPAHILLË/K, -KU m.sh. -QE, -QET hist. Shërbim i spahiut dhe të drejtat e tij. SPIUNLLË/K, -KU m.sh. -QE, -QET bised., përb. Veprimtaria e atij që merret me spiunazh ose që spiunon të tjerët.SYNETLLËK, $-U \mathrm{~m}$. vjet. Ceremoni që zhvillojne myslimanët kur bëjnë djemtë synet. SHEJTANLLË/K, -KU m.sh. -QE, -QET bised. Shejtani. I zoti për shejtanllëqe.TAMAHQARLLËK, -U m. bised. Të qenët tamahqar, lakmi, pangopësi.TARAFLLËK, -KU m.sh. -QE, -QET bised. Miqësitë e sëmura, përkrahje.TERSLLËK, -KU m.sh. -QE, -QET bised. Prapësi.XHAMLLËK, -KU m.sh. -QE, -QET. Ndarje e madhe e një anë të dhomës të ballkonit.XHIBLIK, -U m.sh. -Ë, -ËT. Mbulesë e gjerë prej pëlhure të hollë si rrjetë a prej nape, që lidhet sipër e rreth shtratit për t'u mbrojtur nga mizat e mushkonjat, shtrat i mbrojtur nga një mbulesë e tillë.

\section{Method}

\section{Materials}

The examples included Albanian Language Dictionary of 1954 year and Albanian Dictionaly of 1980 year. Other examples are selected from the literature mositly in Albanian language and Turkish language. The examples for Romanian language are selected from Saineanu, Lazar. In Albanian language we have the articles wrote by Albanian linguist in different periods. But are a lot of study about the influence of Turkish Language in Balkan area. 


\section{Procedure}

Firstly, the words are selected from the Dictionaris of Albanian language. This selection is made for all words borrowed from Turkish Language and all the new words formed with borrowed suffixes from Turkish Language. In this article are selected only the examples with the suffix -lar/-ler and moslty with the suffix -lık/-lik/-luk/-lük. These examples are explained with the meanings that these words have in Albanian language dictionaries.

\section{Results}

The main aim of this study was to evaluate the morphemes -lar/-ler and -lık/-lik/-luk/-lük first of all in Albanian and Turkish language and consecuently in Romanian language. For this purpose, firstly, we are based our study on the theory in respectivly languages for these morphemes. Secondly we give examples from a Dictionary of Albanian language and some other examples in Turkish and Romenian languages.

The morpheme -lar/-ler is used in Albanian language like a plural ending. This morpheme has only same example in which it is used. In Romanian language the morpheme -lar/-ler is not used.

The morpheme -lık/-lik/-luk/-lük are used in all Balkan languages. This morpheme is used in Albanian language and we have a lot of examples of new words formed with this morpheme. In Romanian language this morpheme exist and are used with the borrowed word from Turkish. But in Romanian the suffix -lık/-lik/-luk/-lük didn't formed new words. Today in Romanian language are used the Romanian synonims of these words. In both languages, in Albanian language and in Romenian language can see the trace of Turkish elements, like borrowed words or suffixes. Some of them costitute families of words existed. These elements are part of morphological structure of these languages.

\section{References}

Akademia e Shkencave të Shqipërisë. (1980). Fjalori i gjuhës së sotme shqipe.

Akademia e shkencave të shqipërisë. (2002) Gramatika e gjuhës shqipe I.

Banguoğlu, T. (2000).Türkçenin Grameri, Ankara, TDK Yayınları.

Boretzky, N. (1975). Der Turkische Einfluss auf das Albanische, Tell I: Phonologie und Morphologie der albanische Turkizmen, Wiesbaden.

Boretzky, N. (1976).Der Turkische Einfluss auf das Albanische, Tell II: Worterbuch der albanische Turkizmen, Wiesbaden.

Çabej, E. (1975). Për një shtresëzim kronologjik të huazimeve turke në gjuhën shqipe, në SF 4. 79-85.

Demiraj Sh. (2004). Gjuhesi Ballkanike, Tiranë.

Deny, J. (1926). Turkish Grammer.

Desnickaja, A. (1963). O stilistiçeskoj funkcii turcizmov v albanskom poezii, në "Vopros teorii i istorii jazykov", 86-95.

Dizdari, T. (2005). Fjalori i orientalizmave në gjuhën shqipe, Tiranë.

Ergin M. (1989). Edebiyat ve Eğitim Fakültelerinin Türk Dili ve Edebiyati Bölümleri için Türk Dil Bilgisi, Ankara, Bayrak Yayınları (18. Baski).

Friedman, V. A. (1994) Turkisms in a comparative Balkan context Septième Congrès International d'Études du Sud-Est Européen: Rapports. Athens: Greek National Committee for Southeast European Studies. 521-543.

Grannes A. (1996). Turco-Bulgarica, Article in English and French concerning Turkish influence on Bulgarian, Wiesbaden. Hengirmen, M. (1995) Türkçe Dilbilgisi, Ankara, Engin Yayınları.

Hysa, E. (1973). Disa çështje të parashtesimit në gjuhën shqipe, (SF, Tiranë 1973, Nr.3, 83-100

Hysa, E. (1975). Formimet me parashtesën për- në gjuhën shqipe në "Çështje të gramatikës së shqipes së sotme" II, 86100. 
Hysa, E. (1977). Parashtesat me kuptim mohues në gjuhën shqipe, SF, Nr.4,101-133.

Hysa, E. (1986). Formime me prapashtesën -(ë)ri në gjuhën shqipe, in Studime për nder të A. Xhuvanit.

Hysa, E. (1986). Sindajshtesat dhe vendi i tyre në formimin e fjalëve në gjuhën shqipe SF 2.

Hysa, E. (1986). Sindajshtesat dhe vendi i tyre në formimin e fjalëve, SF Nr.2.

Hysa, E. (1998). Elemente turke në strukturën e fjalës në gjuhën shqipe, SF 3-4, 149-153.

Hysa, E. (2004). Formimi i emrave me ndajshtesa në gjuhën shqipe, 214.

Hysa, E.(1981). Formimi i emrave me parashtesa dhe prapashtesa në gjuhën shqipe, Tiranë 246 f. (Tezë disertacioni për shkallën e parë të kualifikimit pasuniversitar).

Kazazis, K. (1972). The Status Of Turkisms in the present day Balkan Languages.

Korkmaz, Z. (2007). Türkiye Türkçesi Grameri (Şekil Bilgisi), 57.

Kostallari, A. (1978) Rreth depërtimit të turqizmave në gjuhën shqipe gjatë shekujve XVII-XVIII në Gjurmime albanologjike. Seria e Shkencave filologjike. VII, 39-51.

Krajni, A.(1965). Hymja e turqizmave në shqipen dhe përpjekjet për zëvendësimin e tyre, në SF 1, 143-151.

Latifi, L., (2006). Huazimet turke në gjuhën shqipe krahasuar me gjuhët e tjera të Ballkanit, Tiranë.

Lewis, G. Turkish Grammar - Oxford - New York Oxford University Press. Fellow of the British Academi emeritus professor of Turkish in the University of Oxford.

Saineanu, L. (1900). Influenta orientala asupra limbii si culturii române, I-III, Bucuresti.

Samara, M. (1995). Zhvillime leksiko-semantike të turqizmave në gjuhën shqipe SF.

Xhuvani, A. \& Çabej, E. (1962). Prapashtesat e gjuhës shqipe, Tiranë, 1962 and Xhuvani, A. (1980), Vepra I, Tiranë.

Xhuvani, A. \& Çabej, E. (1975). Parashtesat e gjuhës shqipe, in Çështje të gramatikës së shqipes së sotme I and Xhuvani, A. (1980). Vepra I, Tiranë. 